\title{
The Effect of Plant Growth Regulators on Callus Induction and Regeneration of Amygdalus communis
}

\author{
Naimeh SHARIFMOGHADDAM ${ }^{1}$, Abbas SAFARNEJAD²*, Sayed Mohammad TABATABAEI² \\ ${ }^{1}$ Islamic Azad University, Department of Agriculture Biotechnology, Science and Research Branch, Tehran, Iran \\ ${ }^{2}$ Razavi Khorasan Agricultural and Natural Resources Research Center, PO. Box. $91735-$ \\ 1148. Mashhad, Iran; sebre14@yahoo.com (*corresponding author)
}

\begin{abstract}
The Almond (Amygdalus communis) is one of the most important and oldest commercial nut crops, belonging to the Rosaceae family. Almond has been used as base material in pharmaceutical, cosmetic, hygienically and food industry. Propagation by tissue culture technique is the most important one in woody plants. In the current research, in vitro optimization of tissue culture and mass production of almond was investigated. In this idea, explants of actively growing shoots were collected and sterilized, then transferred to MS medium with different concentrations and combinations of plant growth regulators. The experiment was done in completely randomized blocks design, with 7 treatment and 30 replications. After 4 weeks, calli induction, proliferation, shoot length and number of shoot per explants were measured. Results showed that the best medium for shoot initiation and proliferation was MS + 0.5 mg/l IAA (Indol-3-Acetic Acid) $+1 \mathrm{mg} / \mathrm{l} \mathrm{BA}$ (Benzyl Adenine). Autumn was the best season for collecting explants. The shoots were transferred to root induction medium with different concentrations of plant growth regulators. The best root induction medium was MS + 0.5 mg/l IBA (Indol Butyric Acid).
\end{abstract}

Keywords: in vitro, Amygdalus communis, micropropagation, tissue culture, shoot proliferation

\section{Introduction}

The almond (Amygdalus communis) is one of the major tree crops of the world (Kester et al., 1996).

From Middle and West Asia, it has diffused to other regions and continents which include Middle East, China, Mediterranean region and America (Ladizinsky, 1999). Conventional breeding of woody fruit species is a slow and difficult process due to high levels of heterozygosity and long generation cycles (Sriskandarajah et al., 1994).

Because almond is highly heterozygous, and most common commercial cultivars are self-incompatible, almond trees are virtually as variable as wild populations. Vegetation propagation via layerge or cutting is inefficient in order to minimize the problem of the enormous genetic variation and to obtain genetically identical populations, due to the great problems of this fruit species regarding rooting in vivo (Henry et al., 1992).

Also, to maintain clonal purity, seed-derived material is not generally used for propagation. Thus, plant tissue culture techniques are more valuable for the clonal propagation of almond trees. Therefore, the aim of this study was to determine the conditions needed to optimize micropropagation methods for almond, from buds explants by in vitro culture. Yet, there have been no useful protocol on the optimization of propagation of almonds through tissue culture.

\section{Material and methods}

\section{Plant materials}

Actively growing shoots of almonds were collected in four seasons from suitable trees growing at the Agricultural and Natural Resource Research Center of Razavi Khorasan in Iran. After removing the leaves, the shoots were cutted into segments of $1-2 \mathrm{~cm}$ in length, and then washed with running water for 1 hour. After that, the scions were surfaced sterilized in $0.02 \%(\mathrm{w} / \mathrm{v})$ mercuric chloride for 3 min, and then rinsed with $70 \%$ ethanol for $2 \mathrm{~min}$. Later, the segments were sterilized by immersion in $30 \%(\mathrm{w} / \mathrm{v})$ calcium hypochlorite solution, containing $0.05 \%(\mathrm{v} / \mathrm{v})$ Tween 20, for $15 \mathrm{~min}$; finally they were rinsed four times with sterile distilled water.

\section{Micropropagation}

Shoot tips of 0.5 to $1 \mathrm{~cm}$, containing a single bud, were established in tubes containing $20 \mathrm{~mL}$ of Murashig and Skoog (1962) medium (MS), supplemented with $30 \mathrm{gl}^{-1}$ sucrose, $7 \mathrm{gl}^{-1}$ agar (Agar-Agar, Sigma) and different concentrations and types of plant growth regulators (PGRs) (Tab. 3). The $\mathrm{pH}$ was adjusted to 5.8 prior to autoclaving at $120^{\circ} \mathrm{C}$ for $20 \mathrm{~min}$. The cultures were maintained at $25 \pm 2^{\circ} \mathrm{C}$ with $16 \mathrm{~h}$ photoperiod $\left(35 \mu \mathrm{mol} \mathrm{m}^{-2} \mathrm{~s}^{-1}\right)$, provided by white fluorescent lamps. Proliferating axillary shoots were subcultured once every 3 weeks. In the second stage, proliferating shoots were separated and transferred to a 
98

medium containing the same composition. The MS medium without PGRs was used as control. Each treatment was replicated for 30 times. Shoot induction, number of shoot per explants, length of shoot per explants, callusing and rate of infection were reported.

\section{Rooting treatment}

Four weeks old micropropagated shoots were transferred to $20 \mathrm{~mL}$ tubes containing a basal medium of MS with different types and concentrations of plant growth regulators (Tab. 1). The MS medium without PGRs served as control. Each treatment was replicated for 10 times. Rate of root induction, number of shoots and length of roots were records after 4 weeks.

\section{Hardening off}

Plantlets with roots' length between 0.5 and $1 \mathrm{~cm}$ were selected for establishing in green house. Explants were removed from culture and the roots were gently washed in distilled water to remove any residual medium. Then, shoots were potted in 1:2:1 mixture of perlite, sand and soil, respectively. Plantlets were covered with clear borosilicate beaker to maintain a $90 \pm 5 \%$ relative humidity, for 4

Tab. 1. Composition of PGRs used during rooting experiment

\begin{tabular}{ccc}
\hline Treatment Codes & Medium & Composition \\
\hline E & MS & $(1 \mathrm{mg} / \mathrm{l}) \mathrm{IBA}$ \\
$\mathrm{A}$ & $\mathrm{MS}$ & $(0 / 5 \mathrm{mg} / \mathrm{l}) \mathrm{NAA}$ \\
$\mathrm{N}$ & MS & $(0 / 5 \mathrm{mg} / \mathrm{l}) \mathrm{IAA}+(1 \mathrm{mg} / \mathrm{l}) \mathrm{BA}$ \\
$\mathrm{B}$ & $\mathrm{MS}$ & $(1 \mathrm{mg} / \mathrm{l}) \mathrm{NAA}$ \\
$\mathrm{L}$ & MS & $(0 / 5 \mathrm{mg} / \mathrm{l}) \mathrm{NAA}+(0 / 5 \mathrm{mg} / \mathrm{l}) \mathrm{IBA}$ \\
$\mathrm{D}$ & MS & $(0 / 5 \mathrm{mg} / \mathrm{l}) \mathrm{IBA}$ \\
$\mathrm{T}$ & MS & $(0 / 5 \mathrm{mg} / \mathrm{l}) \mathrm{IAA}$ \\
Control & MS &.- \\
\hline
\end{tabular}

weeks, before transferring into the growth room. Relative humidity was slowly decreased by gradually removing beakers. Plantlets were acclimatized after 3 weeks in a green house at $25 \pm 2^{\circ} \mathrm{C}$ under natural daylight conditions.

\section{Experimental design and statistical analysis}

A completely randomized blocks design was used for the study, with data from each experiment being analyzed separately. In micropropagation the treatments were replicated 30 times, and in rooting induction, treatments were replicated 10 times, with each replicate comprising one explants.

The Duncan's test was adjusted at $\mathrm{p}=0.01$ probability level to separate mean differences when significant treatment effects were detected.

\section{Results and discussion}

The best multiple shoot initiation was obtained on the MS medium supplemented with BA at $1 \mathrm{mgL}^{-1}$ and IAA at $0.5 \mathrm{mgL}^{-1}$ (Tab. 1 and 3) with a shoot number of 3.15 per explants, on the $4^{\text {th }}$ week of culture (Tab. 3). The higher length of shoots, with a shoot length of $1.21 \mathrm{~cm}$ and the most callus initiation, with 9.5, were observed on MS medium supplemented with the same PGPs as the above (Tab. 3). Conclusions show that BA treatments caused better shoot proliferation and better shoot multiplication (Fig. 1, 2, 3).

The results indicated that between the different seasons, autumn was the best time for collecting explants from trees on the field (Tab. 4). There were significant differences between the rate of contaminations and the dates of collecting the explants (Tab. 2).

Tab. 2. Summary of treatment interaction as determined analysis of variation for shoot proliferation

\begin{tabular}{ccccccc}
\hline Source of variation & df & Rate of contamination & Callus initiation & Shoot length $(\mathrm{cm})$ & Shoot number & Shoot induction \\
\hline Date of collecting explants & 3 & $107753 / 96^{* *}$ & $0 / 86^{* *}$ & $1 / 44^{* *}$ & $8 / 95^{* *}$ & $1.14^{* *}$ \\
\hline PGRs treatment & 6 & $554 / 56^{* *}$ & $1 / 10^{* *}$ & $1 / 78^{* *}$ & $12 / 89^{* *}$ & $1.05^{* *}$ \\
$\begin{array}{c}\text { Date of collecting explants } \\
\times \text { PGRs treatment }\end{array}$ & 18 & $149 / 80 \mathrm{~ns}$ & $0 / 07 \mathrm{~ns}$ & $0 / 14 \mathrm{~ns}$ & $0 / 97 \mathrm{~ns}$ & $0 / 06 \mathrm{~ns}$ \\
$\quad$ Error & 812 & $2032 / 84$ & $0 / 14$ & $0 / 11$ & $0 / 78$ & $0 / 11$ \\
\hline
\end{tabular}

${ }^{*} \mathrm{p} \leq 0.05 ;{ }^{*} \mathrm{p} \leq 0.01$; ns no significant

Tab. 3. Effect of different PGRs treatment on shoot proliferation

\begin{tabular}{ccccccc}
\hline $\begin{array}{c}\text { Treatment } \\
\text { codes }\end{array}$ & $\begin{array}{c}\text { Composition of } \\
\text { PGRs treatment }\end{array}$ & $\begin{array}{c}\text { Mean rate } \\
\text { contamination }\end{array}$ & $\begin{array}{c}\text { Mean } \\
\text { callusing }\end{array}$ & $\begin{array}{c}\text { Mean shoot } \\
\text { length }(\mathrm{cm})\end{array}$ & $\begin{array}{c}\text { Mean shoot } \\
\text { number }\end{array}$ & $\begin{array}{c}\text { Mean Shoot } \\
\text { induction }\end{array}$ \\
\hline $\mathrm{N}$ & $\mathrm{IAA}(0 / 5 \mathrm{mg} / \mathrm{l})+\mathrm{BA}(1 \mathrm{mg} / \mathrm{l})$ & $42 / 91 \mathrm{a}$ & $9 / 5 \mathrm{a}$ & $1 / 21 \mathrm{a}$ & $3 / 15 \mathrm{a}$ & $9 \mathrm{a}$ \\
$\mathrm{H}$ & $\mathrm{BA}(2 \mathrm{mg} / \mathrm{l})+\mathrm{IBA}(0 / 01 \mathrm{mg} / \mathrm{l})$ & $42 / 91 \mathrm{a}$ & $7 \mathrm{ab}$ & $0 / 77 \mathrm{cb}$ & $2 / 57 \mathrm{~b}$ & $6 / 25 \mathrm{~b}$ \\
$\mathrm{~J}$ & $\mathrm{TDZ}(4 \mathrm{mg} / \mathrm{l})$ & $39 / 58 \mathrm{a}$ & $5 / 75 \mathrm{~b}$ & $0 / 84 \mathrm{~b}$ & $1 / 93 \mathrm{c}$ & $6 \mathrm{bc}$ \\
$\mathrm{K}$ & $\mathrm{IBA}(0 / 01 \mathrm{mg} / \mathrm{l})+\mathrm{BAP}(1 / 27 \mathrm{mg} / \mathrm{l})$ & $37 / 50 \mathrm{a}$ & $5 / 5 \mathrm{~b}$ & $0 / 6 \mathrm{~cd}$ & $1 / 52 \mathrm{~cd}$ & $4 / 5 \mathrm{bc}$ \\
$\mathrm{F}$ & $\mathrm{IBA}(0 / 01 \mathrm{mg} / \mathrm{l})+\mathrm{BAP}(0 / 68 \mathrm{mg} / \mathrm{l})$ & $37 / 91 \mathrm{a}$ & $5 / 75 \mathrm{~b}$ & $0 / 73 \mathrm{cb}$ & $1 / 57 \mathrm{~cd}$ & $4 / 5 \mathrm{bc}$ \\
$\mathrm{C}$ & $\mathrm{IAA}(0 / 1 \mathrm{mg} / \mathrm{l})+\mathrm{BA}(1 / 5 \mathrm{mg} / \mathrm{l})$ & $40 / 41 \mathrm{a}$ & $4 / 75 \mathrm{~b}$ & $0 / 75 \mathrm{cb}$ & $1 / 67 \mathrm{~cd}$ & $3 / 8 \mathrm{c}$ \\
Control & --- & $40 / 41 \mathrm{a}$ & $0.0 \mathrm{~d}$ & $0.0 \mathrm{~d}$ & $0.0 \mathrm{~d}$ & $0.0 \mathrm{~d}$ \\
\hline
\end{tabular}

Values with the same letters in the same column are not significantly different $(p \leq 0.01)$ according to Duncan's test 
Tab. 4. Effect of different date of collecting explants on shoot proliferation

\begin{tabular}{cccccc}
\hline $\begin{array}{c}\text { Date of collecting } \\
\text { explants }\end{array}$ & $\begin{array}{c}\text { Mean rate } \\
\text { contamination }\end{array}$ & $\begin{array}{c}\text { Mean } \\
\text { callusing }\end{array}$ & $\begin{array}{c}\text { Mean shoot length } \\
(\mathrm{cm})\end{array}$ & $\begin{array}{c}\text { Mean shoot } \\
\text { number }\end{array}$ & $\begin{array}{c}\text { Mean shoot } \\
\text { induction }\end{array}$ \\
\hline May & $36 / 19 \mathrm{~b}$ & $7 \mathrm{ab}$ & $0 / 81 \mathrm{~b}$ & $2 / 43 \mathrm{~b}$ & $5 / 83 \mathrm{~b}$ \\
August & $39 / 76 \mathrm{~b}$ & $5 / 6 \mathrm{cb}$ & $0 / 72 \mathrm{c}$ & $1 / 95 \mathrm{c}$ & $4 \mathrm{bc}$ \\
November & $15 \mathrm{c}$ & $9 / 3 \mathrm{a}$ & $0 / 98 \mathrm{a}$ & $3 / 57 \mathrm{a}$ & $8 / 5 \mathrm{a}$ \\
February & $70 \mathrm{a}$ & $3 / 8 \mathrm{c}$ & $0 / 67 \mathrm{c}$ & $1 / 90 \mathrm{c}$ & $3 / 75 \mathrm{c}$ \\
\hline
\end{tabular}

Values with the same letters in the same column are not significantly different $(\mathrm{p}=0.01)$ according to Duncan's test

Tab. 5. Summary of treatment determined analysis of variance for shoot proliferation

\begin{tabular}{ccccc}
\hline $\begin{array}{c}\text { Source of } \\
\text { variation }\end{array}$ & df & $\begin{array}{c}\text { Root length } \\
(\mathrm{cm})\end{array}$ & $\begin{array}{c}\text { Root } \\
\text { number }\end{array}$ & $\begin{array}{c}\text { Root } \\
\text { induction }\end{array}$ \\
\hline Treatment & 8 & $2 / 103^{* *}$ & $3 / 07^{* *}$ & $0 / 9^{* *}$ \\
Error & 81 & $0 / 239$ & $0 / 362$ & $0 / 128$ \\
\hline
\end{tabular}

${ }^{*} \mathrm{p} \leq 0.05 ;{ }^{* *} \mathrm{p} \leq 0.01$

Tab. 6. Effect of different PGRs treatment on rooting stage

\begin{tabular}{lccccccccc}
\hline Treatment & Control & $\mathrm{T}$ & $\mathrm{N}$ & $\mathrm{L}$ & $\mathrm{B}$ & $\mathrm{A}$ & $\mathrm{E}$ & $\mathrm{D}$ \\
\hline $\begin{array}{c}\text { Mean root } \\
\text { induction }\end{array}$ & $0 \mathrm{c}$ & $0 \mathrm{c}$ & $1 \mathrm{cb}$ & $2 \mathrm{~b}$ & $3 \mathrm{~b}$ & $3 \mathrm{~b}$ & $6 \mathrm{a}$ & $7 \mathrm{a}$ \\
$\begin{array}{c}\text { Mean root } \\
\text { number }\end{array}$ & $0 \mathrm{c}$ & $0 \mathrm{c}$ & $1 / 2 \mathrm{~b}$ & $1 / 2 \mathrm{~b}$ & $1 / 37 \mathrm{ab}$ & $1 / 3 \mathrm{~b}$ & $1 / 92 \mathrm{a}$ & $2 / 11 \mathrm{a}$ \\
$\begin{array}{c}\text { Mean root } \\
\text { length }(\mathrm{cm})\end{array}$ & $0 \mathrm{c}$ & $0 \mathrm{c}$ & $2 / 8 \mathrm{a}$ & $0 / 85 \mathrm{~b}$ & $0 / 79 \mathrm{~b}$ & $0 / 93 \mathrm{~b}$ & $1 / 2 \mathrm{a}$ & $1 / 7 \mathrm{a}$ \\
\hline $\begin{array}{l}\text { Values with the same letters in the same column are not significantly different } \\
\text { (p=0.01) according to Duncan's test }\end{array}$
\end{tabular}

The best root formations were observed in MS medium supplemented with $0.5 \mathrm{mgL}^{-1} \mathrm{IBA}$ (Tab. 6). The maximum number of root induction was 7 , the mean value for roots per seedling was 1.92 and for root length was $2.8 \mathrm{~cm}$, data obtained on MS medium supplemented with $0.5 \mathrm{mgL}^{-1}$ and $1.0 \mathrm{mgL}^{-1} \mathrm{IBA}$, for the firts two (treatments $\mathrm{D}$ and $\mathrm{E}$, respectively) and with $\mathrm{MS}$ medium $+0.5 \mathrm{mgL}^{-1} \mathrm{IAA}+1.0$ $\mathrm{mgL}^{-1}$ IBA for the last expriment (Tab. 3). No root development was observed in control groups.

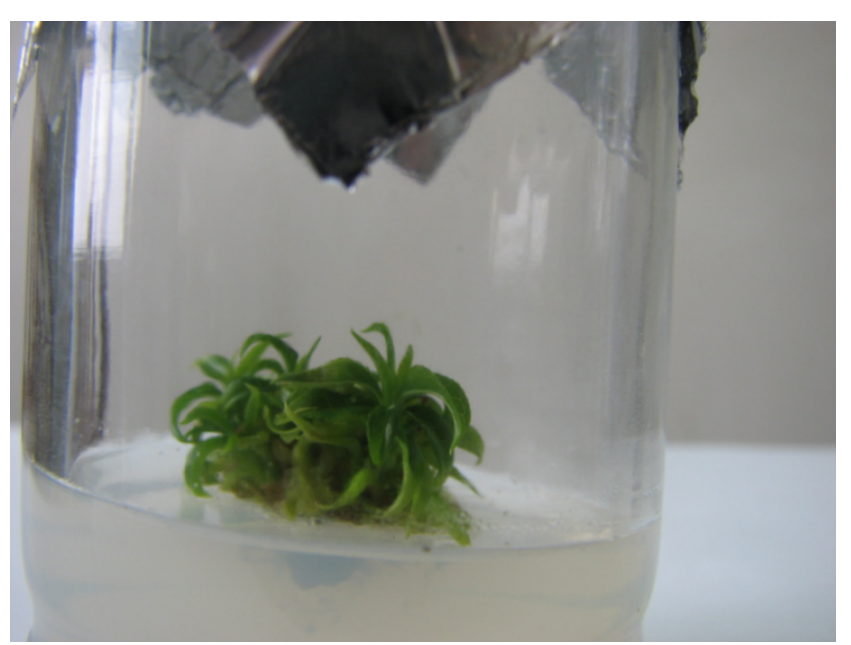

Fig. 1. Multiple shoot proliferation on a MS medium with IAA $\left(0.5 \mathrm{mgL}^{-1}\right)$ and $\mathrm{BA}\left(1 \mathrm{mgL}^{-1}\right)$
The present results are in agreement with Tabachnic and Kester (1977) observations. They reported that the use of BA in shoot multiplication was absolutely necessary.

Hisajima (1982) reported that the best result for proliferation of the almond was obtained from MS medium supplemented with $0.2 \mathrm{mgL}^{-1} \mathrm{BA}+0.005 \mathrm{mgL}^{-1} \mathrm{IBA}$.

Isikalan et al. (2008) determined that the best multiple shoot initiation for almond was obtained on the MS medium supplemented with BA $2 \mathrm{mgL}^{-1}$, with a shoot number of $5.7 \pm 1.04 \mathrm{mgL}^{-1}$ per explant.

Increasing BA concentration from $1 \mathrm{mgL}^{-1}$ to $3 \mathrm{mgL}^{-1}$ may significantly reduce the length of shoots, as observed by Shekafandeh and Khush-khui (2008) in guava (Psidi-

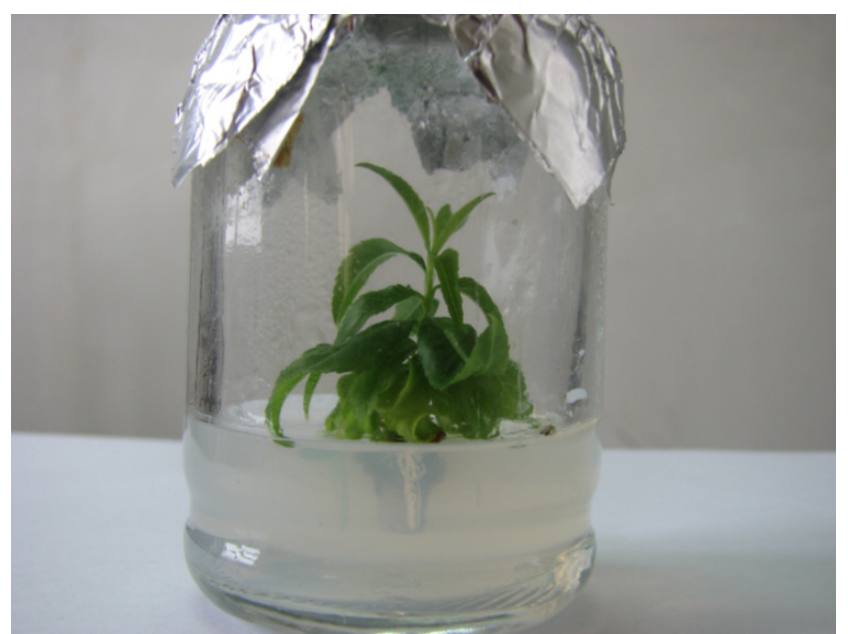

Fig. 2. Developed shoot on a MS medium with IAA $\left(0.5 \mathrm{mgL}^{-1}\right)$ and $\mathrm{BA}\left(1 \mathrm{mgL}^{-1}\right)$

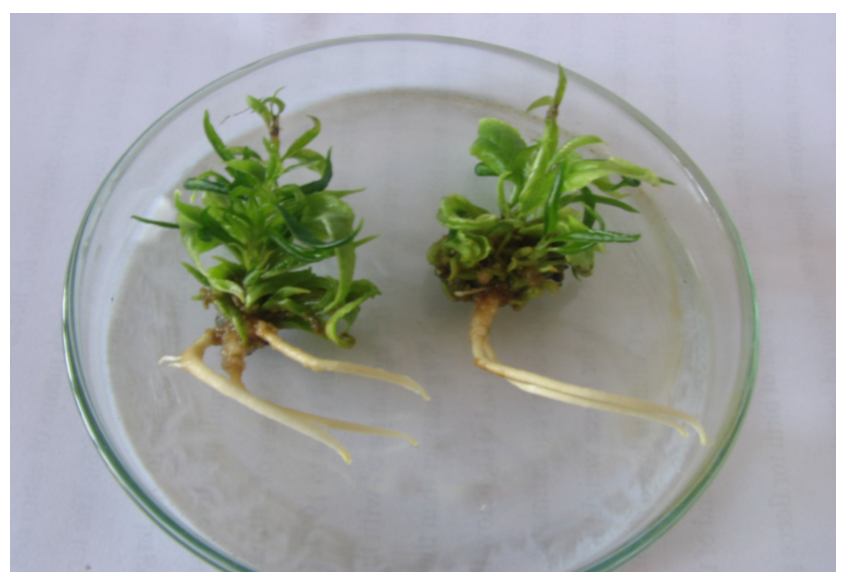

Fig. 3. Seedlings on MS medium with IBA $\left(0.5 \mathrm{mgL}^{-1}\right)$ 
100

um guajava, Myrtaceae). Ahmad et al. (2004) reported that IBA is the preferable auxin for in vitro rooting of peach rootstock GF677 and the maximum number of roots and root length were obtained when applying $0.4 \mathrm{mgL}^{-1} \mathrm{IBA}$.

Besides plant grow regulation factors, the year's seasons have been observed to influence in different degrees the micropropagation of temperate cultures. Shahrzad and Emam (2000), for instance, reported that summer and early autumn were the best times for collecting Populous euphratica explants in order to shoot proliferation. Nasiri (2000) show that mid autumn is the best time for taking explants from Olea europaea trees.

The present experiments demonstrated that shoot multiplication could be achieved on MS medium supplemented with $1 \mathrm{mgL}^{-1} \mathrm{BA}$ and $0.5 \mathrm{mgL}^{-1}$ IAA. BA treatments resulted in a better elongation of almond scion. However, MS medium with $0.5 \mathrm{mgL}^{-1} \mathrm{IBA}$ was also effective for root induction and root elongation.

After 3 weeks, rooted shoots of almond were acclimatized and then were successfully transferred to natural condition. Channuntapipat et al. (2003) showed that the maximum rooting of shoots for some almond hybrid rootstocks occurred on half strength MS medium with 2.4 $\mathrm{mgL}^{-1}$ IBA. Ainsley et al. (2001) determined that IBA and NAA are the most suitable auxin for rooting seedlings of 'Nec plus ultra' and 'Nonpariel' almond cultivars, in vitro conditions.

The type and concentration of auxin during rooting period strongly influenced the quality of the root system during rooting period. The application of NAA resulted in poor rooting of the almond shoots. This might be explained by the NAA resistence to degradation by the auxin-oxidase enzyme (Smulders et al., 1990). Nissen and Sutter (1996) have shown that, in tissue culture, media IAA is rapidly photo-oxidized ( $50 \%$ in $24 \mathrm{~h}$ ), while the IBA oxidized slowly $(10 \%)$ and NAA is very stable.

\section{Conclusions}

The results obtained in the present research can be used as guidelines for improving propagation of almond as a commercial fruit tree. In addition, the results demonstrated which is the optimized stage for root induction. Since in micro propagation rooting of micro cutting is often a challenging step, losses at this stage have vast economic consequences. In conventional propagation via cuttings many woody plants are also recalcitrant to root. Thus, a research on root formation is highly important from the practical point of view. It can be conclude that proliferation and multiplication of almond by tissue culture is a fast, economic and valuable method.

\section{Acknowledgments}

The authors are grateful to the Razavi Khorasan Agricultural and Natural Resources Research Center.

\section{References}

Ahmad T, Ur-Rahman H, Laghari MH (2004). Effect of different auxin on in vitro rooting of peach rootstock $\mathrm{GF}_{677}$. Sarhad J Agricult 20(3):373-375.

Ainsley PJ, Collins GG, Sedgley M (2001). In vitro rooting of almonds (Prunus dulcis Mill). In vitro Cell Develop Biol Plant 37(6):778-785.

Channunapipat C, Sedgley M, Collins G (2003). Micropropagation of almond cultivars "Nonpareil" and "Ne plus ultra" and the hybrid rootstock, "Titan $\times$ Nemgard". Sci Hort 98:473-484.

Henry PH, Blazich FA, Hinesley LE (1992). Vegetative Propagation of eastern red cedar by stem cuttings. Hort Sci 27(12):1272-1274.

Hisajima S (1982). Multiple shoot formation from almond seeds and an excised single shoot. Agricult Biol Chemi 46:10911093.

Isikalan C, Adiyaman Akbas F, Namli S, Tikat E, Basaran D (2008). In vitro micropropagation of almond (Amygdalus communis L. Cv. "Nonpareil"). Afr Biotechnol 7(12):18751880.

Kester DE, Gradziel TM (1996). Almonds. In: Janick J, Moore JN (Eds.). Fruit breeding, Vol III: NUTS. New York: John Wiley and Sons, Inc.

Ladizinsky G (1999). On the origin of almond. Genetic Resour Crop Evolut 46:143-147.

Murashige T, Skoog F (1962). A revised medium for rapid growth and bioassays with tobacco tissue cultures. Physiol Plant 15:473-497.

Nasiri M (2000). Micropropagation of olive (Olea europeae). Iranian Rangeland and Forest Plant Breeding and Genetic Res J 230:37-79.

Nissen SJ, Sutter EG (1990). Stability of IAA and IBA in nutrient medium of several tissue culture procedures. Hort Sci 800-802.

Sharzad SH, Emam M (2000). Micropropagation of populus euphratica using tissue culture. Iran Rangeland Forest Plant Breed Genetic Res J 230:11-36.

Shekafandeh A, Khush-Khui M (2008). Effect of bud position and culture medium on prolifiratin from nodal culture of two guava cultivars. Asian J Plant Sci 7:177-182.

Smulders MJM, Van Devan ETWM, Croes AF, Wullems GJ (1990). Metabolism of 1-naphthaleneacetic acid in explants of tobacco: evidence for release of free hormone from conjugates. J Plant Growth Regul 9:27-34.

Sriskandarajah S, Goodwin PB, Speirs P (1994). Genetic transformation of the apple scion cultivar delicious via Agrobacterium tumefaciens. Plant Cell Tissue Organ Cult 36:317-329.

Tabachnik L, Kester DE (1977). Shoot culture for almond and almond-peach hybride clones in vitro. Hort Sci 12:545-547. 